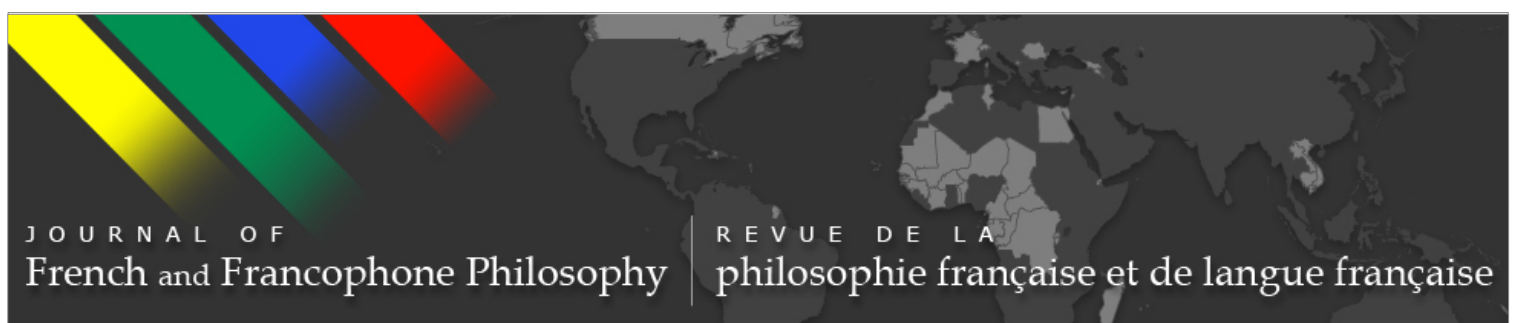

\title{
Eating Well with Pleshette DeArmitt
}

Sarah Kathryn Marshall

Journal of French and Francophone Philosophy - Revue de la philosophie française et de langue française, Vol XXIII, No 2 (2015) pp 45-49

\author{
Vol XXIII, No 2 (2015) \\ ISSN 1936-6280 (print) \\ ISSN 2155-1162 (online) \\ DOI 10.5195/jffp.2015.699 \\ www.jffp.org
}

\section{(oc) BY-NG-ND}

This work is licensed under a Creative Commons Attribution-Noncommercial-No Derivative Works 3.0 United States License.

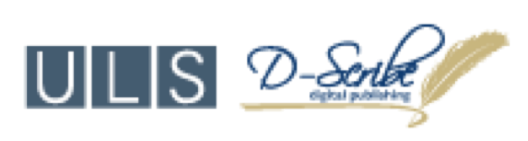

This journal is operated by the University Library System of the University of Pittsburgh as part of its D-Scribe Digital Publishing Program, and is co-sponsored by the University of Pittsburgh Press 


\title{
Eating Well with Pleshette DeArmitt
}

\author{
Sarah Kathryn Marshall
}

The University of Memphis

Every work is an occasional work: this simply means that each work has a beginning, that it begins at a certain moment in time and that that moment in time is a part of the work, since without it the work would have been only an insurmountable problem, nothing more than the impossibility of writing it. ${ }^{1}$

-Maurice Blanchot

The piece that follows is an occasional work, ${ }^{2}$ begun "with nothing in mind," nothing: the single, unbearable thought that Pleshette is no more. ${ }^{3}$ It is irrevocably inscribed in a certain moment to which I found myself unable to return, reappropriate, incorporate, or unify into another work après coup. ${ }^{4}$ More than anything, I wish that this work had been only an insurmountable problem, a mere impossibility. The fact remains that I wrote it in mourning; as a work of morning, it was not impossible plain and simple, but rather impossible in its "unavoidable betrayal" of the other and yet its "absolute fidelity" to her-to Pleshette, whom I "must and must not get over." ${ }^{5}$

$* * *$

Pleshette was a gifted storyteller. When we first met, she was on sabbatical, completing what was to become her book. I was visiting Memphis as a prospective doctoral student, and she graciously made a trip in to campus to share a meal with me. Over Garibaldi's "Vegetarian Pizza," which the franchise considers to be "gourmet," our first conversation was about eating well. Pleshette began to recount some of her successes and struggles with ethical eating, including her experiences with French meals during her time abroad. She told me the story of one such meal, during which she and Kas were served cow tongue, la langue. Pleshette expressed her own distaste for the course and endearingly poked fun at Kas's unreserved enjoyment of the dish. Despite her resistance to this foreign tongue, she nevertheless partook of an unfamiliar custom.

Looking back, this encounter has come to condense the image I have of Pleshette, an image that revolves around so many meals, and in which the

Journal of French and Francophone Philosophy | Revue de la philosophie française et de langue française Vol XXIII, No 2 (2015) | www.jffp.org | DOI 10.5195/jffp.2015.699 
personal and the academic are significantly intertwined. At the time, however, I knew nothing of Pleshette's scholarly engagement with Derrida's work, more specifically, on eating well, impossible mourning, and the remains or the leftover, both translations of the French le reste. My limited study of the French language included neither le reste nor the idiom il faut bien manger. I learned the latter phrase from Pleshette over a meal we shared with Seraphine and Marygrace Hemme at a crêperie in the 15th arrondissement. Il faut bien manger, meaning both "one must well eat" and "one must eat well," is an injunction not only to eat, to nourish oneself, but also to take enjoyment in doing so; the English, "If you've gotta' do something, you might as well do it well," captures something like the sentiment expressed in il faut bien manger.

In the image I have of her, Pleshette eats well. Echoing the words of Rousseau, Kristeva, and Derrida (on whom I will focus my remarks here), Pleshette wrote her own book. In The Right to Narcissism: A Case for an Impossible Self-Love, she gives us the thought of a self-love that is made possible only through the love of and for another. Pleshette takes in Ovid's Narcissus and transforms him. The experience Narcissus has of himself at the pond is mediated by another's love-Echo's love-a love he doesn't recognize as such. No longer the self-absorbed, closed-off tragic figure of myth, or at least not merely, Pleshette's Narcissus must mourn his inability to be sufficient unto himself. This is the condition of every "subject," self, or "I."

In a 1989 interview titled "'Eating Well,' or the Calculation of the Subject," Derrida contends that what has been called "The Subject" is a fable. ${ }^{6}$ But the fabulous nature of this subject is not, on his view, grounds for its "simple liquidation." 7 Rather, Derrida argues, "The Subject" must still be taken seriously, since this conception of subjectivity continues to influence the discourses of many of its most profound critics (including Lacan, Levinas, and Heidegger). As traditionally conceived, the philosophical subject is master of itself, autonomous, and self-identical. Responsibility, and hence morality, have been theorized on this basis. Derrida is critical of this understanding of subjectivity, because it is grounded upon a sacrifice of the alterity constitutive of what it is to be a self. For him, the relation of the self to itself is characterized by différance: the self is always already differing from and deferring itself; it is other than itself from the very beginning. ${ }^{8}$ Any self, according to Derrida, establishes its own identity by taking in that which is other and reappropriating it, thereby making it its own. What has been called "The Subject" owes its existence to the necessary interiorization or incorporation of the other. The other, however, can never be fully assimilated into the self-same; alterity "resists all subjectivation." ${ }^{9}$ There is something that remains, something leftover, something indigestible.

From this, Derrida concludes that the moral question becomes "how, for goodness' sake, should one eat well?"10 One must take in the other, and one

Journal of French and Francophone Philosophy | Revue de la philosophie française et de langue française

Vol XXIII, No 2 (2015) | http://www.jffp.org | DOI 10.5195/jffp.2015.699 
must give the other to eat. This "metonymy of introjection" calls for an ethics. ${ }^{11}$ Eating well, Derrida reminds us, "must be nourishing not only for me, [...] it must be shared."12 And sharing a meal means "learning and giving to eat," because "[o]ne never eats entirely on one's own." ${ }^{13}$ What Derrida calls "metonymical eating" evokes a law requiring "respect for the other at the very moment when [...] one must begin to identify with the other, who is to be assimilated, interiorized, understood ideally." ${ }^{14}$ Such respect demands that one address oneself to the other, "speak to him or her in words that also pass through the mouth, the ear, and sight." ${ }^{15}$ All this in a tongue that is and is not one's own.

It comes as no surprise to those who know her that, in her recounting of Ovid's tale, Pleshette champions the oft-neglected, sacrificial, feminine character. Truly, Echo is the hero of Pleshette's book. She writes, "[i]t almost seems as if Echo ' $\mathrm{knew}^{\prime}$ that by reiterating Narcissus's phrases, by allowing his words and sounds to pass through her mouth, she would be able to draw him nearer to her, begin to identify with him, and ultimately respond to her beloved by appropriating his locutions for herself." 16 Echo eats well. "When Echo appears to be merely miming Narcissus," Pleshette understands her to be "in fact attempting the impossible-to appropriate the unappropriable, the foreign, the transcendent, the absolutely or wholly other."17 Repeating Narcissus's words, addressing his words back to him, "Echo not only speaks her own name but also declares her love." 18

This love respects the other and makes possible the ethical relation. Pleshette observes that "it is Echo's love that infuses and gives new life to the words of Narcissus."19 In Echo's "seemingly simple reply," Pleshette hears an acknowledgement accepting "that the other has always come before me and that I am forever speaking the other's language, borrowing it from him in order to speak to him." ${ }^{20}$

Echo's words will have never been mere echoes. And this is how I remember Pleshette's teachings. Her lectures were "close readings," echoes, one might say, but not merely. Pleshette made others' words her own. She conveyed something novel and inspiring through the considered, reassuring, and rhythmic quality of her speech. She always told the story anew, and her presentation unfailingly came across with the force of a confidence at the same time subversive and respectful.

Pleshette would always insist on rearranging the classroom in such a way that we could all face each other. This involved everyone getting up and awkwardly working together to create a giant circle. Once this task was accomplished, we would gather around, much like a family meal, and take in Pleshette's words. Pleshette knew how to eat well, and she knew what it meant to share it. The furniture in Clement 213, that dreadful, asbestosplagued, wasp-inhabited, cave-like room, remains in Pleshette's round-table 
arrangement. Her echoes resound there and elsewhere, continuing to nourish us and reminding us to nourish others.

Le reste de Pleshette DeArmitt: what remains of her? what has she left over? There is the photo in circulation, memorializing her piercing gaze and wry smile. There is the work she and Kas were writing-on le reste, no less. And there is her commitment to what is left over, what remains outside of a philosophical system, what gets sacrificed for the formation of any subject, what resists incorporation: the indigestible, le vomit. There is the rest of Pleshette DeArmitt, whose exemplary alterity I will never fully ingest, though the im-possibility of mourning her sustains me. Through the loving declaration of her words, I will continue to ruminate on her image, to eat well, as she taught me to do, and to share this food only she could have given us to think.

Maurice Blanchot, "Literature and the Right to Death," in The Work of Fire, trans. by Charlotte Mandell (Stanford: Stanford University Press, 1995), 305.

2 Exclusive of the introductory remark, this piece was delivered at a memorial session for Pleshette on Friday, May $1^{\text {st }}, 2015$ at a conference she planned in honor of the 25 year anniversary of the doctoral program at the University of Memphis.

3 Blanchot, "Literature and the Right to Death," 304.

${ }^{4}$ Pleshette DeArmitt, The Right to Narcissism: A Case for an Im-possible Self-love (New York: Fordham University Press, 2014), 116.

${ }^{5}$ DeArmitt, The Right to Narcissism, 115.

6 Jacques Derrida, “'Eating Well,' or the Calculation of the Subject," in Points, trans. by Peter Conner and Avital Ronell (Stanford: Stanford University Press, 1995), 264. In the Spring of 2015, Pleshette and Kas Saghafi had been co-teaching a course titled "Derrida and the Ethics and Politics of Sacrificial Economy." The syllabus marks April $23^{\text {rd }}$ as the date on which Pleshette was to deliver a lecture on this interview. Pleshette will have never given this lecture. There is no doubt much to be said about the fact that this text figures centrally in my reading of The Right to Narcissism after Pleshette's death. The French title of this interview is "Il faut bien manger, ou le calcul du sujet." See Jacques Derrida, "Il faut bien manger, ou le calcul du sujet: Entretien (avec J.-L. Nancy)," in Confrontations 20: 91-114.

${ }^{7}$ Derrida, “Eating Well," 255.

8 Derrida, “Eating Well," 261.

9 Derrida, “Eating Well," 271.

10 Derrida, “Eating Well,” 282.

Journal of French and Francophone Philosophy | Revue de la philosophie française et de langue française Vol XXIII, No 2 (2015) | http://www.jffp.org | DOI 10.5195/jffp.2015.699 
11 Ibid.

12 Ibid.

13 Ibid.

14 Derrida, “Eating Well,” 283.

15 Ibid.

${ }^{16}$ DeArmitt, The Right to Narcissism, 128.

17 Ibid.

${ }^{18}$ DeArmitt, The Right to Narcissism, 136.

${ }^{19}$ Ibid.

${ }^{20}$ DeArmitt, The Right to Narcissism, 134.

Journal of French and Francophone Philosophy | Revue de la philosophie française et de langue française Vol XXIII, No 2 (2015) | http://www.jffp.org | DOI 10.5195/jffp.2015.699 